\title{
Introduction
}

\section{Space and Time or the Poetics of Oral History}

\author{
Movement must be at the very heart of lis- \\ tening. \\ Eudora Welty ${ }^{1}$
}

Time passes, moves through us, conferring an evanescent quality to our lives. Listening to each other is "stirring" for the heart, as time and space converge. The oral historian turned illusionist embarks on a journey to past unseen things, transforming them, through language, into visible transubstantiations. The space where historian and informant meet is filled with a tempo, a rhythm, a revelation. Movement is at the heart of it all.

Since the beginning of my career some thirty years ago, my historical analysis has been informed by an exploration of the shadows. Using the lens of gender to identify and illuminate the dark interstices of time and place, I began by exploring gendered official discourses as expressed in the laws and decrees of both the Francoist state apparatus and the Catholic Church. In my first book, True Catholic Womanhood: Gender Ideology in Franco's Spain, ${ }^{2}$ I focused on the Francoist university and the various Catholic women's organizations that represented the ideal notion of what I called "True Catholic Womanhood." Building on this ideal in my second book, The Seduction of Modern Spain: The Female Body and the Francoist Body Politic, ${ }^{3}$ I sought to further understand how gender ideology informed the state's tight control of public morality through the censorship and repression of popular culture. This work delved into the somatic metaphors used in National Catholic rhetoric to better understand the correlation between the gendered human body and the Francoist bio-power. In this new book I paint the third panel in the tryptic by focusing, not on official state discourses or mass communication, but on the counter discourses articulated by ordinary people experiencing the twilight of Franco's regime.

Eudora Welty, One Writer's Beginnings (Cambridge, MA: Harvard University Press, 1995), 11.

2 Aurora C. Morcillo, True Catholic Womanhood: Cender Ideology in Franco's Spain (Dekalb: Northern Illinois University Press, 2000, 2008).

3 Aurora C. Morcillo, The Seduction of Modern Spain: The Female Body and the Francoist Body Politic (Lewisburg: Bucknell University Press, 2010). 
In Part 1, I focus on the stories of middle class, well-educated college student activists in the 1960s and 1970s. In Part 2, I shift to the narratives of women from working class families with little or no formal schooling. Together, these two perspectives form a more complete, balanced picture of everyday resistance to the regime's control. I title this work (In)visible Acts of Resistance to highlight the pervasiveness of the struggle to break through the strictures imposed by Franco's regime, and the heroic acts of ordinary people made in the name of survival. The weight of so many individual acts of resistance by those portrayed in this work, and the many more just like them, helped break down the regime's control, and set the tone for the successful transition to democracy that was to come.

The interviewees are individuals outside of mainstream history. Their stories represent the substratum of what Miguel de Unamuno, in his work En torno al casticismo (1902), called intra-history: ${ }^{4}$

The newspapers say nothing about the silent life of millions of men without a history who, at all times and in all parts of the world, get up with the sun and go about their obscure, silent, eternal daily work in the fields, the work upon which, much like the sub-oceanic reefs, the islets of history are erected. ${ }^{5}$

As Javier Krauel points out, Unamuno's concept of the intra-history affords us a new sense of personhood, which downplays political and economic aspects of the superficial historical narrative in favor of an intra-historical exploration of a more authentic being in time.

Therefore, this study aspires to shed light on ordinary acts of resistance rather than headline-grabbing events that typically serve historical narrative. As Howard Eiland and Kevin McLaughlin point out, Walter Benjamin's intent in The Arcades Project was to show a "primal history" only possible to realize through "cunning":

[I]t was not the great men and celebrated events of traditional historiography but rather the "refused" and "detritus" of history, the half-concealed, variegated traces of the daily life of "the collective;" that was to be the object of study. ${ }^{6}$

Oral history is the tool of choice in this study to aid in the "cunning" process of unveiling the visible and invisible strategies of self-empowerment utilized by ordinary people in spite of the Francoist regime's attempts at control in the late 1960s and early 1970s. The theoretical and methodological rationale used to examine the informants' narratives draws from philosophy, but also includes urban, literary, and

Peggy Watson, Intra-historia in Miguel de Unamuno's Novel: A Continual Presence (Potomac, Maryland: Scripta Humanistica, 1993).

5 Miguel de Unamuno, En torno al casticismo (Madrid: Alianza Editorial, 2000), 40.

6 Eiland and Kevin McLaughlin, "Translators' Foreword," in The Arcades Project, by Walter Benjamin (Cambridge, MA: Harvard University Press, 1999), ix. 
gender studies. The notes that follow address oral historiography from the perspective of autobiographical and memory studies, utilizing the vectors of time and space. Oral history represents an apt instrument of analysis to better understand how space and time collide in the construction of historical narration.

I draw from urban theory as proposed in the work of Henri Lefebvre's (19011991) Critique of Everyday Life to analyze the lives of citizens affected by the changes in demographics following the Spanish Civil War (1936-1939). Spain's rapid urbanization led to the proliferation of shanty towns on the edges of major cities such as Madrid, Barcelona, and Bilbao. Neighborhood associations with their ad-hoc governing councils sprang up and would later become legitimate political voices for the labor movement. Urbanization was also a response to the transition from post-war economic isolation (autarky) to an open consumer economy fed by American dollars (The Pact of Madrid in 1953). Mass migration after the civil war, both inside and outside the country, added to the growth of Spain's urban centers and the dislocation of its people. The examination of the layout of the city of Granada in the late 1960s and early 1970s is used to show the meaning of space as conceived and experienced over time.

The stories should be read as creative non-fiction, or ficto-critical narrations, following María Zambrano's focus on emotions and the invisible connections they articulate among us, which guides the analysis of the narration. ${ }^{7}$ The stories are not just told plainly, but "poeticized." Ficto-criticism is particularly fruitful in the realm of autobiography within cultural studies. As Anna Gibbs explains:

Fictocriticism does not illustrate an already existing argument, does not simply formulate philosophy (or anything else) in fictional terms. It is not translation or transposition: it says something which can't be said in any other way: because it is not reducible to propositional content. It is, in essence, per-formative, a metadiscourse in which the strategies of the telling are part of the point of the tale. ${ }^{8}$

The goal is to prioritize a lyrical narrative to better capture the emotional landscape of late Francoism. The interviews uncover how people creatively resisted and trespassed figurative and physical boundaries set up by Franco's Cold War, a technocratic, modernizing project. tion," Text 1, no. 2 (1997). See also on art-based research: Thomas Barone and Eliot Eisner, Arts Based Research, 1st ed. (Thousand Oaks, CA: SACE Publications, 2011); Heather Kerr and Amanda Nettelbeck, The Space Between - Australian Women Writing Fictocriticism (Perth, AU: UWA Publishing, 1998); Elizabeth Pattinson, "Discovering the Self: Fictocriticism, Flux and Authorial Identity" http://www.aawp.dreamhosters.com/wp-content/uploads/2015/03/Pattin son2013.pdf.

8 Gibbs, "Bodies of Words." 
Finally, the last aspect to consider when reading the narratives is my own autobiographical narrative, placed strategically throughout the book. ${ }^{9}$ These provoked memories, rooted in the spatial and temporal remembrances of the informants, transported me back to the point in time in which they occurred. Time and space, like a fresh water river meeting salty ocean in a brackish delta, mix and merge in my writing. When shaping each individual's story, I was unable to avoid my own presence as a young girl, bearing silent witness to their struggles.

In the final analysis, the oral history practice opens the door to a new historical pursuit, one that leads to a creative historical ontology in which the history we learn is a history of becoming rather than being. The collected interviews expose how both college students and homemakers articulated their resistance in the comings and goings of daily life. Identifying the tactics and practices ordinary Spanish women used to survive the regime makes visible their micro-transgressions of conventional norms. But these women did more than just survive; they also calculatingly worked to better the odds of their daughters overcoming limited expectations and opportunities. They did this by instilling in them a sense of independence, desire, and even defiance.

There are three methodological lenses applied to the analysis of the narratives in this book: 1) Henri Lefebvre's Critique of Everyday Life through what he called Rhythmanalysis of the urban space; 2) María Zambrano's "Poetic reason" through creative non-fiction or ficto-criticism; and 3) Auto-biography/life writing as intrinsic to the oral history process. The ultimate goal is the exploration of oral history as a valuable, humanistic tool to better understand the role of time and space in historical writing when the primary sources at hand are oral interviews and our own DNA.

\section{The Purpose of History: A Creative Historical Ontology}

In his book The End of History, Lefebvre questions history's master narratives or les grands récits. He instead speaks of le sens de l'histoire. The term "sense" in French implies both directional and semantic connotations. The directional connotation is

Ronald Grele calls it "conversational narrative," as it is the result of the exchange between the interviewer and the informant in which both shape the outcome of the conversation. While the informant provides the story, the ultimate author of the narrative resulting from the interview is the interviewer. See Ronald Grele, "Private Memories and Public Presentation: The Art of Oral History," in Envelopes of Sound: The Art of Oral History, ed. Ronald Grele (New York, London: Praeger, 1991), 257-58. See also: Lynn Abrams, Oral History Theory (London: Routledge, 2010); Miren Llona, ed., Entreverse: Teoría y metodología practica de las fuentes orales (Bilbao: UPV, 2012); Pilar Domínguez, Rina Benmayor, and María Eugenia Cardinal de la Nuez, eds., Memory, Subjectivities, and Representation: Approaches to Oral History in Latin America, Portugal, and Spain (New York: Palgrave Macmillan, 2016). 
understood as the "end of" or "purpose of" history, while the semantic connotation is understood as the meaning or signification of the historical process. History is chaos without a purpose or meaning. ${ }^{10}$

Turning the historian's task into a pursuit of understanding of our human condition endows it with a "sense," a "purpose." The traditional positivistic History might hence be overcome and radically altered. In other words, the sense of history (directional and semantic) resides in an exercise of cunning interrogation towards introspection and empathy. ${ }^{11}$ The historical importance of ordinary actions carried out by "insignificant" people is what this book is all about. Therefore, in searching for historical signification, this book puts oral history in conversation with philosophy (Gilles Deleuze, Maurice Merleau-Ponty, Henri Bergson, María Zambrano), and cultural, literary, and urban studies from a gender perspective. Intersecting all these vectors brings to light issues of periodization and location-time and space-entangled in the historical unfolding as becoming rather than being in time.

I propose to dwell in the "moment" when time and space traverse each other. To freeze a moment in time through narrative retelling allows us to gain insight into the actions and choices made by people living unspectacular lives. Spanish historian Miren Llona proposes the notion of "memory's enclaves" or anchors as privileged mental sites (moments) to which individuals return to peek down and feel past emotions. These memory enclaves act as mental repositories of images that over the individual's lifetime have merged with their sense of self in relation to particular personal past experiences. Llona further explains how the memories stored in those enclaves are recurring and resilient to oblivion. No doubt, forgetting is intrinsic to remembrance, ${ }^{12}$ an essential element in organizing fragmentary

10 As Stuart Elden explains: "There is a plurality of times, of physical, biological, social, cyclical and linear times, which overlap and conflict in various ways. [...] If there is nothing fundamental about time then history is a fiction [my emphasis] or an abstraction." Lefebvre bases his argument on Nietzsche's understanding of the modern world and his notion of "civilization" which would imply a radical break with "historicity, the historic, the past and its knowledge as useless excess, burdens on the memory, more and more sterile inventories of the accomplished. The birth of this civilization implies a radical break, a total discontinuity, a renewal of methods of knowledge, and a repudiation of historical thought." Stuart Elden, Understanding Henri Lefebure: Theory and the Possible (London: Continuum, 2004), 176-77.

The discipline of history emerges simultaneously with the rise of nationalism at the end of the nineteenth century. But Lefebvre actually identifies its origins in Ancient Greece, just as the city-state is born. History develops from "insignificant tales, [du récit anecdotique] annals, and epic poems to talk about the constitution to tell of the struggles of the city state." Therefore, he suggests that "history did not just emerge to tell any story, but a particular one, that of the state" and its power. Elden, Understanding Henri Lefebvre, 177-78.

12 On forgetting and the importance of oblivion see: Harald Weinrich, Lethe: The Art and Critique of Forgetting (Ithaca: Cornell University Press, 2004); Paul Ricoeur, Memory, History, Forgetting 
recollections into a coherent narrative. Therefore, it seems imperative to apply an analysis of those repetitions, of those (eternal) returns to the "memory enclaves" (or moments), both linear and cyclical rhythmic returns, which in the moment of the interview come alive. But I would further propose that the way the informant revisits the enclave is also in every instance unique. ${ }^{13}$ We construct our life stories anew every time we retell them because their meaning is always chasing the context in which they are told.

The individual reconstructs her life's story from the social and collective parameters in place at each historical juncture; however, the meaning of the collective story can only gain depth through an analysis of the individual rêcit anecdoques. As Max van Manen points out, "what makes anecdotes so effective is that they seem to tell something noteworthy or important" about the quotidian. The anecdote serves as an example of a concrete moment in place when the agency of the informant is revealed.

What everyday practices allowed women to sustain and fulfill individuality and agency under dictatorial rule? Were these women able to have an impact on the opportunities and self-esteem of their daughters? Listening to their evaluation of their own lives reveals subtle truths. Instead of just passively going along with the regime, they calculatingly taught their daughters to have greater expectations than they would dare allow themselves. Instead of indoctrinating them in the limiting role of the true Catholic woman, they were inoculating them against its harmful effects.

\section{The Visible: Space's Rhythmanalysis}

The rhythmanalyst [...] will be attentive, but not only to the words or pieces of information, the confessions and confidences of a partner or client. He will listen to the world, and above all to what are disdainfully called noises, which are said without meaning, and to murmurs [rumeurs], full of meaning -and finally he will listen to silences.

Henri Lefebvre, Elements of Rhythmanalysis $(2004)^{14}$

(Chicago: Chicago University Press, 2006); Marc Auge, Oblivion (Minneapolis: University of Minnesota Press, 2004); Svetlana Boym, The Future of Nostalgia (New York: Basic Books, 2002). 
The Francoist regime's longevity is inextricably tied to the economic developments of the 1960s. Therefore, it makes sense to study the social and political dynamics emerging from that modernizing moment. The industrialization and urbanization unleashed a radicalization of the opposition to the dictatorship, coalescing around the labor and student movements. The study of these movements in the Spanish context provides a deeper understanding of the global social unrest that unfolded in what has been called the long 1960s.

Henri Lefebvre's multidisciplinary work puts in conversation a variety of disciplines: geography, history, sociology, literary criticism, urban studies, and philosophy. Regarded as one of the godfathers of the 1968 French student movement, he was at the time a professor in Nanterre and had developed a close relationship with avant-garde groups like Cobra, Situationists International, and Letterist International. Ultimately, Lefebvre's critique of everyday life in post-World War II European cities offers us methodological tools to help uncover the workings of capitalism. Lefebvre identified the urban environment as the site of both control and resistance to alienation. Therefore, Lefebvre's framework will help illuminate the means used by the Francoist regime to maintain power. By pivoting to the West in the aftermath of the Second World War, Franco ensured his relevancy to the outside world and protected his regime's power from outside meddling. His new role as benign dictator opening his country up to the West and fighting the common Communist enemy helped satisfy the conscience of his new American partners, who saw Spain as having democratic possibilities. Authoritarianism replaced fascism, as the American dollars and military aid flowed in. Although Spain was originally excluded from the Marshall Plan, or the European Recovery Program, in 1948, its strategic importance to Cold War anti-Communist policies made it a natural partner. Only five years later, in 1953, the Pact of Madrid was signed by the two new allies. This newfound friendship was further consecrated by an embrace between President Eisenhower and dictator Francisco Franco when the US president visited Spain in 1959.

Industrialization and its ensuing urbanization, helped by United States economic aid, was at the heart of the regime's international rehabilitation but also central to understanding the dynamics of social interaction in the urban environment. The urban transformation came with problems of overcrowding, as rural mass migration to the developed industrial urban poles (Barcelona, Bilbao, and Madrid) exploded. The Ministry of Housing and the Instituto Nacional de Industria (INI) became key agencies in the deployment of the capitalist economy orchestrated by the Opus Dei's skilled technocratic planning. Space turned into a crucial site of power for the regime. As Lefebvre makes clear, space is crucial to understanding the transition from a "use-value city" to one where the priority is exchange and

14 Henri Lefebvre, Elements of Rhythmanalysis (London, Oxford: Continuum, 2004), loc 301 of 1306, Kindle. 
consumption-what he calls "exchange-value city." That change is clearly manifest in the Francoist transition from autarky (self-sufficient post-war economic isolation) to capitalist consumerism, and from pseudo fascist to National Catholic to better fit the international propagandist image of "Sentinel of the West." Lefebvre points out how "capitalist leaders treat everyday life as they once treated colonized territories: massive trading posts (supermarkets and shopping centers); ${ }^{15}$ absolute predominance of exchange over use; dual exploitation of the population in their capacity as producers and consumers." 16 Technocracy turned out to be the new means to create a rationalized conformity, representing modernization without compromising state control of space(s), both symbolic and physical. While Franco reluctantly agreed to the Americanization of the economy, his tight technocratic urban planning offered the promise of continuity of order, conformity, and ultimate authoritarian control.

In The Production of Space (1991), Lefebvre elaborates a dialectical triad of space to understand its fluid nature: first, what he calls "conceived space" or representational space produced by urban planners and economic technocrats; second, "lived space" or spaces of representation involving hidden symbolism; and third "perceived space" or spatial practices where individuals implement their own autonomous movements in between reestablished zones. College students would trespass physical and symbolic boundaries in their daily comings and goings, as they moved from their middle-class enclaves to working-class neighborhoods to recruit and educate, and in and out of their symbolic roles as students and activists. Female students more specifically would be in the university and at the same time be "out of"17 Even the spaces and hours of the day were gendered, male or female, friendly or threatening.

Alejandro Gómez del Moral's dissertation entitled "Buying into Change: Consumer Culture and the Department Store in the Transformation(s) of Spain, 1939-1982" (PhD diss., Rutgers University, 2014) is a ground-breaking study that intersects gender, consumption, and modernization during the Francisco Franco dictatorship.

16 Henri Lefebvre, Critique of Everyday Life: From Modernity to Modernism (Towards a Metaphilosophy of Everyday Life), Vol. 3 (London, New York: Verso, 2005), 26.

17 The Francoist university was ruled by the Ley de Ordenación Universitaria (LOU, Regulatory University Law) issued in 1943, which was replaced with the enactment of the General Law of Education in 1970. As I have explained in my previous work the Francoist National Catholic rhetoric forged an ideal "True Catholic Womanhood" based on the revival of the counterreformation values of purity and subordination of the 1500 s as proposed in Luis Vives' The Instruction of the Christian Woman (1523) and Fray Luis de Leon's The Perfect Wife (1583). This ideal womanhood was inimical to the intellectual subjectivity constructed by the letter of the LOU. See: Aurora Morcillo, "Gendered Activism: The Anti Francoist Student Movement in the University of Granada in the 1960 s and 1970s," Gendered Education in History, Theory and Practice-Case-Studies on Womeris Education, Gendered Spaces and Performativity of Knowledge, Encounters in Theory and History of Education, 19 (2018): 90-109, and True Catholic Womanhood. 
The rich literature on feminist geography emerging in the 1980 s gives form to the social relations in space and time. The works of feminist geographers like Gillian Rose and Doreen Massey are crucial to our more sophisticated understanding of how gender, space, and time are inseparable. ${ }^{18}$ The informants in the narratives made self-conscious choices to transgress those urban zones and bio-political (gendered) limitations. As women, they entered the male-centered space of the university where they were implicitly excluded or "out of place"19 as the Regulatory Law of the University-in place from 1943 to 1970-defined them. Being a university student was seen as an affront to the official discourse on true Catholic womanhood. ${ }^{20}$ In many instances, the university students interviewed for this study asserted themselves by becoming "one more of the guys." ${ }^{21}$ The small transgressive choices each informant revealed in the interviews are illuminating as a historical account of invisible acts of resistance and empowerment. While the urban landscape was their visible space of action, the impetus behind their decision to move from one zone to another is only revealed through a new understanding of spatiality and temporality, placing time and space in a dialectical, continuous engagement.

Implicit in this conceived, lived, perceived spatial triad is Lefebvre's critique of alienation-particularly relevant for our understanding of the student and labor movements' historical agency in late Francoism. According to Lefebvre, alienation is encountered, suffered, and negotiated in every aspect of everyday life and administered through the spatial triad he establishes for the urban environment. In the process of negotiating these alienating dynamics we are actually able to discern the atomized nature (Foucauldian) of power relations. In accordance with the "theory of the moment," our ability to transgress socio-political expectations in different alienating encounters through sometimes invisible tactics and strategies is at the heart of people's agency and self-empowerment. According to Lefebvre, in the words of Stuart Elden, "moments are significant times when existing orthodoxies are open to challenge, when things have the potential to be overturned or radically altered, moments of crisis in the original sense of the term." 22 This inter-

18 Gillian Rose, Feminism and Geography: The Limits of Geographical Knowledge (Oxford: Polity Press, 1993); Doreen Massey, Space, Place and Gender (Cambridge: Polity Press, 1994); Linda McDowell and Joanne P. Sharp, A Feminist Clossary of Human Geography (London: Arnold, 1999); Lise Nelson and Joni Seager, A Companion to Feminist Ceography (Oxford: Blackwell, 2005); and Geraldine Pratt, "Feminist Geographies: Spatialising Feminist Politics," in Envisioning Human Geographies, ed. Paul Cloke, Philip Crang, and Mark Coodwin (London: Arnold, 2004), 128-45. See Massey,Space, Place and Gender, 130-34.

20 See Morcillo, True Catholic Womanhood.

21 See Socorro and Marga stories.

22 Elden further points out how the moment has a long tradition in Western thought from Kierkegaard and Nietzsche. The latter is particularly relevant to Lefebvre. "In Nietzsche's Thus 
est in the moment explains Lefebvre's close, though ephemeral, collaboration with the Situationists International movement. A member of a radical group of artists located in Paris, known as Letterists International, Guy Debord (1931-1994) founded the Situationist movement, which gathered interest in the First World Congress of Free Artists celebrated in Alba, Italy, in 1956. A year later, several avant-garde actions launched the movement. ${ }^{23}$ The movement criticized the capitalist consumer society as profoundly alienating and fanned by spectacle. Their name "Situationist" referred to their strategies to raise consciousness by creating "situations" or "moments" in the public space to provoke a shift in behavior by using the shock factor, with the intention to reignite true meaning and purpose in life. The students at the Spanish universities enacted "critical trials" against their professors in lecture halls, where they challenged academic authority and demanded a radical change in the content of their studies. It was precisely around the synergy between the theory of the moment, elaborated by Lefebvre, and the "construction of Situations" by the Situationists, that the collaboration between the two started. ${ }^{24}$

The situation, as a created, organized moment-Lefebvre expresses this desire as "the free act defined as the capacity ... to change a 'moment' in metamorphosis, and perhaps to create one"-includes perishable instants, ephemeral and unique.

Spoke Zarathustra," Stuart Elden points out, "the moment, the Augenblick, the blink of an eye, is a gateway where past and future collide." Stuart Elden, "Rhythmanalysis: An Introduction," in Rhythmanalysis: Space, Time and Everyday Life, by Henri Lefebvre (London, New York: Continuum, 2004), loc. 52 of 1306, Kindle.

23 Some of the groups included: Letterist International, the International Movement for an Imaginist Bauhaus, and the London Psychogeographical Association.

24 In an interview Lefebvre pointed out the origins of the movement and his connection with them: "During the postwar years, the figure of Stalin was dominant. And the Communist movement was the revolutionary movement. Then, after ' 56 or ' 57 , revolutionary movements moved outside the organized parties, especially with Fidel Castro. In this sense, Situationism wasn't at all isolated. Its point of origin was Holland-Paris, too—but Holland especially, and it was linked to many events on the world stage, especially the fact that Fidel Castro succeeded in a revolutionary victory completely outside of the Communist movement and the workers' movement. This was an event. And I remember that in 1957 I published a kind of manifesto, Le romantisme révolutionnaire, which was linked to the Castro story and to all the movements happening a little bit everywhere that were outside of the parties. This was when I left the Communist Party myself. I felt that there were going to be a lot of things happening outside the established parties and organized movements like syndicates. There was going to be a spontaneity outside of organizations and institutions-that's what this text from 1957 was about. It was this text that put me into contact with the Situationists because they attached a certain importance to it-before attacking it later on. They had their critiques to make, of course; we were never completely in agreement, but the article was the basis for a certain understanding that lasted for four or five years - we kept coming back to it." Henri Lefebvre, "Henri Lefebvre on the Situationist International," interview by Kristin Ross, 1983. $\mathrm{h}$ ttp://www.notbored.org/lefebvre-interview.html. 


\section{$[\ldots]$}

The "moment" is mainly temporal, forming part of a zone of temporality, not pure but dominant. Articulated in relation to a given place, the situation is completely spatio-temporal [...] Moments constructed into "situations" might be thought of as moments of rupture, of acceleration, revolutions in individual everyday life. On a more extended-more social—spatial level, an urbanism that almost exactly corresponds to Lefebvre's moments, and to his idea of choosing these and leaving them behind at will, has been proposed in the "states-of-the-soul quarters." 25

Guy Debord published The Society of the Spectacle in 1967, and Belgian philosopher Raoul Vaneigem published The Revolution of Everyday Life the following year. These texts had a profound impact on university protests originating in Nanterre and later spreading to Paris in May 1968. Raoul Vaneigem was fascinated by Lefevbre's critique of everyday life and sent an essay on "poetry and revolution" to his professor who in turn put him in contact with Debord. Both Lefevbre and Vaniegem would leave the Situationists and dissociate themselves from Debord by 1960. According to Lefebvre, "Debord's dogmatism was exactly like Breton's. And, what's more, it was a dogmatism without a dogma, since the theory of situations, of the creation of situations, disappeared very quickly, leaving behind only the critique of the existing world, which is where it all started, with the Critique of Everyday Life." 26

While the classroom "critical trials" represented a visible example of the construction of a Situationist moment, the less theatrical trials of homemakers, working class individuals who raised their daughters and sons in quiet opposition, represented invisible Situationist moments. They existed, certainly, but like ultraviolet light, they were unnoticed, hiding past the limits of human perception. The second part of this book focuses on these unseen, daily acts of defiance deployed by working class women and how these acts had a profound impact on the next generation.

In The Revolution of Everyday Life (1967), Vaneigem sought to explain how to give significance to the insignificant, to the instance that transforms repetition in order to enrich the monotonous routine of the quotidian. ${ }^{27}$ "The enrichment of life calls inexorably," he wrote, "for the analysis of the new forms taken by poverty, and the perfection of the old weapons of refusal." The path to enrichment is, in Vaneigem's view, a creative one deeply rooted in imagination. It is taken consciously to escape an alienation derived from the obsession with comfort and the implicit happiness wrought by the modern, affluent capitalist society:

25 "The Theory of Moments and the Construction of Situations," Internationale Situationniste \#4, (1960) http://www.notbored.org/moments.html.

26 Lefebvre, interview.

27 Raoul Vaneigem, "The Insignificant Signified," in The Revolution of Everyday Life (London: Rebel Press, 2006), 21-29. See also a 2009 interview with Vaneigem in http://www.e-flux.com/jour nal/06/61400/in-conversation-with-raoul-vaneigem/. 
People without imagination are beginning to tire of the importance attached to comfort, to culture, to leisure, to all that destroys imagination. This means that people are not really tired of comfort, culture and leisure, but of the use to which they are put, which is precisely what stops us enjoying them.

The affluent society is a society of voyeurs. To each his own kaleidoscope: two fridges, a VW, TV, a promotion, time to kill.... But then the monotony of the images we consume gets the upper hand, reflecting the monotony of the action which produces them, the slow rotation of finger and thumb that in turn rotates the kaleidoscope. [...]

People who talk about revolution and class struggle without referring to everyday life, without understanding what is subversive about love and what is positive in the refusal of constraints-such people have a corpse in their mouth. ${ }^{28}$

Urban alienation, according to Vaneigem, trumps all other forms of alienation and therefore offers us the ideal site to observe the conflicting urges to embrace and at the same time reject the rising consumerism in Spain during the 1960s and 1970s. It is not surprising that many Spanish youth turned from the alienation and empty promise of consumer culture by joining either the radical Christian movements such as FECUN (Federación Española de Comunidades Universitarias) or the Communist Party of Spain (PCE). It is also not surprising that working class mothers turned toward consumerism and its modernizing force as an escape from their alienation, and as a way for their daughters to break through the confining carapace of "True Catholic Womanhood."

The city is situated, according to Lefebvre, halfway between "near order" or faceto-face individual and group relations, and "far order" or society regulated by institutions like the Church, the State, the University, the Army, etc. The materialization in the urban landscape is a matter of "scale" assigned to zones (neighborhoods, shanty towns, institutional buildings such as colleges or police stations) and groups (civil, university, and religious authorities versus the student and workers organizations) which reveal different levels of influence and power as each city zone was allotted to a specific group. The scale here is understood as a social construction rather than simply a matter of a space's size, which is also always in flux. Doreen Massey addresses the issue of scale when considering the embodied/gendered nature of space. It is necessary to distinguish between space and place within the space, and to think of social space in terms of a site where social relations play out. Therefore, "one way of thinking of place," Massey argues, "is as particular moments 
in such intersecting relationships." ${ }^{29}$ Male and female spaces are so by virtue of the embodied experience of those spaces, and each space constructs gender specific places. "Thinking of places in this way implies that they are not so much bounded areas, as open and porous networks of social relations. ${ }^{30}$ According to Kate Driscoll Derickson, Lorraine Dowler, and Nicole Laliberte, Massey's

"analysis of 'sense of place' adds another dimension to feminist understandings of space, that of scale. She argues that the connection of the everyday practices of women can be linked to societal relationships, at which point these experiences can be 'stretched out' and understood in a local, regional, and sometimes global context."31

This is ultimately a rethinking of the historian's task and brings to the fore the fruitful use of oral history. According to Massey, "The past is not more authentic than the present; there will be no one reading of it. And 'traditions' are frequently invented or, if they are not, the question of which traditions will predominate cannot be answered in advance. It is people, not places themselves, which are reactionary or progressive." 32 In her essay, "A Woman's Place?" Massey looks at the realignment of gender relations in four different geographical locations in the UK in the mid 1960 s as a result of government economic reorganization. The development plans launched by the Francoist regime in the 1960s created similar economic poles of development that led to the realignment of gender relations in Spain. There was a redefinition of the construction of masculinity and femininity as urbanization, migration, and tourism re-signify multiple spaces, both physical and symbolic. The different development poles during Francoism led to challenges in the way patriarchy had to be realigned. The poor regions (Andalusia or Galicia) saw their men leave to find work in the urban areas or to other European countries. Wives, in many cases left behind, had to raise children alone. However, the men continued to maintain economic dominance as the sole breadwinners. When women migrated, they experienced new mores and had to adjust to them accordingly. I am echoing here Massey's argument: "The contrasting forms of economic development in different parts of the country [she is referring to the UK, but it fits Spain in this analysis] presented distinct conditions for the maintenance of male dominance [...] capitalism presented patriarchy with different challenges in different parts of the

\footnotetext{
29 Massey, Space, Place and Gender, 119.

30 Massey, Space, Place and Gender, 120.

31 Kate Driscoll Derickson, Lorraine Dowler, and Nicole Laliberte, "Advances in Feminist Geography," in The International Studies Encyclopedia, ed. Robert A. Denemark and Renée MarlinBennett (Hoboken: N], Wiley-Blackwell, 2017), 5. 
country." ${ }^{33}$ Massey is referring to 1960 s and 1970s economic developments in different regions in the UK, but obliquely she highlights the historical experience of the working class in all of Europe during that period. It is important to point out that the economic transformations described by Massey were carried out by the Labor Party while the development plans in Spain were the work of an authoritarian regime led by Opus Dei technocrats. These circumstances become more apparent when we introduce the variable of gender into the examination of time and space. Interestingly, Spain surfaces in Massey's work when she notes how Henri Lefebvre himself pointed out the sexualization of the space in his work The Production of Space:

Picasso's space heralded [sic] the space of modernity...What we find in Picasso is an unreservedly visualized space, a dictatorship of the eye-and of the phallus; an aggressive virility, the bull, the Mediterranean male, a machismo [sic] (unquestionable genius in the service of genitality) carried to the point of self-parody-and even on occasion to the point of self-criticism. Picasso's cruelty towards the body, particularly the female body, which he tortures in a thousand ways and caricatures without mercy, is dictated by the dominant form of space, by the eye and by the phallus-in short by violence. ${ }^{34}$

Lefebvre's analysis of everyday life allows us to delve into his reconceptualization of the assumptions behind history and his understanding of historicity, temporality, and their spatiality. For Lefebvre, time and space must be thought of together, and in no other instance are both intertwined better than in the practice of oral history.

Historians and economists examine the rhythms of eras, their cycles, their slowness or rapidity. They are not, however, able to measure the tiny repetitions of daily life, the repetitions that fill the majority of our lives. History focuses not so much on the repetition but the break from routine. It is the unusual that wakes us from our slumber. The truth is that the rhythm, or repetition, is the fact and truth of most lives. "What is repetition?" Lefebvre askes, "What is meaning? How, when and why are there micro and macro re-starts, return to the past in works and time? Therefore, 'not only does repetition not exclude differences, it also gives birth to them." 35 Sooner or later, the formulaic "once upon a time" happens and introduces a variable into the monotonous, mechanical repetition; such is the moment, the difference. Those differences constitute the thread of time and in the moment of the interview, the invisible resistance to routine and everyday life becomes visible. 
The oral history process brings to life the cyclical and linear repetitions. The former originating on the natural unfolding of days, months, seasons, etc.; the latter more the result of the social practices and structural impositions in the conversation between informant and oral historian's time and space. The cyclical and the linear collide and measure themselves against each other. Measure is key here as it is consubstantial to rhythm. The duration of a particular act of self-assertiveness, concealed over decades and unearthed in the interview, discloses the rhythm, the measure of invisibility, the calculated project (both in spatial and temporal dimensions) that is agency. Duration is quantified and qualified by measure like a song's melody or the meter of a poem. Rhythm must be analyzed.

\section{The Invisible: Time's Poetic Reason}

Because poetry will not accept what already has "number, weight and measure," [...] but will find the number, weight and measure that corresponds to what still does not have it.

María Zambrano, Filosofía y poesía ${ }^{36}$

Rhythmanalysis is of great value for the practice of oral history. It works as a conduit into a history of emotions through an attentive study of signification. Lefebvre posed the question: "What makes the measurable and the non-measurable?" I pose a similar question: what makes the visible and the invisible? Under the construct of measurement exist several sub-constructs: repetition and difference; mechanical and organic; discovery and creation; cyclical and linear; continuous and discontinuous; and quantitative and qualitative. It is my hunch that the answer to what makes the invisible visible can be found in the human ability to construct meaning based on the context of time and place. In oral history as life writing, what individuals say about their history is determined not just by past events but also the present. The narrative is a negotiated account agreed upon by past and present selves. What emerges is of necessity, a dialogic compromise between the younger and the older versions of the informant. This introspection leads to an understanding of not just the individual but the very human condition that is the purpose of history.

How best to uncover the humanity of history? I propose an alternative understanding of oral history writing informed by the concept of poetic reason afforded

36 "Porque la poesía no va a captar lo que ya tiene 'número, peso y medida, [...] sino que va a encontrar el número, peso y medida que corresponde a lo que todavia no lo tiene." María Zambrano, Filosofía y Poesía (Mexico: Fondo de Cultura Económica, 1996), 88-89. My translation. 
by Spanish philosopher María Zambrano (1904-1991). History in general and oral history in particular is a system of signification, ${ }^{37}$ which is gendered, racialized, and quantified through the collaborative process of the (inter)view. Making the world intelligible is the common purpose of history and language. Such purpose is fulfilled in narration. The mode of writing warns the reader of the message the author wants to express beyond just language. When we see a poem on a page, we read it differently than when we are presented with an account of facts. Writing contains signs that indicate its relation to society and history. ${ }^{38}$ Historical writing claims to be neutral and transparent, but the rejection of any literariness in historians' craft confers to it a recognizable historical écriture.

The analysis of the interviews contained in this book allows me to create a distance from historical écriture. Each narrative inspired a free verse poem, most selected from known poets; some I ventured to write myself. These poems intend to capture the self-empowering moment revealed by each informant. Each story's poem exposes in simple words a profound signification. They are the poetic rendition of the eternal return to the memory enclaves that Miren Llona warned us about. The simplicity and impressionistic nature of the poems encapsulates what I, as a historian, am in search of: revealing what feminist/gender historians advanced theoretically, what we called "becoming visible"39-poetizing these stories has the power to transform something invisible into something luminous. Walter Benjamin tells us, "The true image of the past flits by. The past can be seized only as an image which flashes up at the instant when it can be recognized and is never

37 The concept of signification Roland Barthes proposed is applied in the examination of these interviews to decipher the historical meaning of insignificant actions carried out by ordinary people. Roland Barthes in his 1968 work entitled Elements of Semiology explains his concept of "systems signification." "There is at present a kind of demand for semiology, stemming not from the fads of a few scholars, but from the very history of the modern world... Now it is far from certain that in the social life of today there are to be found any extensive systems of signs outside human language." Roland Barthes, Elements of Semiology (New York: Hill and Wang, 1977), 9. For Barthes, there is no meaning outside of language. "Working with no linguistic substances," he writes, "semiology requires, sooner or later, to find language." Thus, Barthes' semiology is that part of linguistics that covers the great signifying unities of discourse. In this way, semiology helps us understand the significance of the narratives sought in oral histories. Jonathan Culler points out how "no prose is transparent, as Sartre would wish. Even the simplest language of novels_-Hemingway, for example or Camus—signifies by indirection a relationship to literature and to the world. A stripped-down language is not natural or neutral or transparent but a deliberate engagement with the institution of Literature; its apparent rejection of literariness will itself become a new mode of literary writing, a recognizable écriture as Barthes calls it." Jonathan Culler, Roland Barthes: A Very Short Introduction (Oxford: Oxford University Press, 1983), loc. 428 of 2267, Kindle.

39 Renate Bridenthal, Susan Stuard, and Merry E. Wiesner-Hanks, Becoming Visible: Women in European History, $3^{\text {rd }}$ ed. (Belmont, CA: Wadsworth Publishing,1997). 
seen again. [...] For every image of the past that is not recognized in the present as one of its own concerns threatens to disappear irretrievably." 40

The exploration and analysis of these narratives utilizing Zambrano's poetic reason may help us map a piece of the history of emotions under the Franco dictatorship. Moreover, this analytical approach promises to shed some light on feminist historiographical concerns: periodization, agency, and authenticity versus truth in the utilization of gender as a category of analysis. To make intelligible the symbolism behind these women's experiences is to pursue a creative historical ontology-a poetics of history.

Poetizing the stories into short verses slows time, allowing for more leisurely contemplation. Since writing history is about the conceptualization of time and periodization, it is also gendered. As Walter Benjamin wrote: "History is the subject of a structure whose site is not homogeneous, empty time, but time filled by the presence of the now [Jetztzeit]" and declares that "a historical materialist cannot do without the notion of a present which is not a transition, but in which time stands still and has come to a stop. For this notion defines the present in which he himself is writing history." 41

Lefebvre points out that starting with the conceptual brings with it a series of risks: "speculation in place of analysis, the arbitrarily subjective in place of facts." 42 And yet, it is incumbent upon us to take this risk, as Zambrano proposes, to be able to "find the number, weight, and measure" that correspond to those things which "still does not have it"-our emotions:

Pleasure and joy demand a re-commencement. They await it; yet it escapes. Pain returns. It repeats itself since the repetition of pleasure gives rise to pain(s). However, joy and pleasure have a presence, whereas pain results from an absence (that of a function, an organ, a person, an object, a being). Joy and pleasure are, they are being; not so suffering. Pessimists used to affirm the opposite: only suffering is, or exists. The propositions that precede ground an optimism, in spite of everything. 43

The same optimism inspires the examination of these narratives, as I choose to dwell, poetically, in the joyful assertive moments that gave hope to these women trapped in the bleak landscape of Francoism.

\footnotetext{
40 Walter Benjamin, "Theses on the Philosophy of History," in Illuminations (New York: Schocken Books, 2007), 254, eBook.

41 Benjamin, "Theses on the Philosophy of History," 61-262.

42 Lefebvre, Elements of Rhythmanalysis, loc. 134 of 1306, Kindle.

43 Lefebvre, Elements of Rhythmanalysis, loc. 218 of 1306, Kindle. Italics in the original.
} 


\title{
Oral History as Life Writing or The Making of the Self
}

\author{
Oral sources are generated in a dialogic ex- \\ change - an interview-literally a looking \\ at each other, an exchange of gazes. \\ Alessandro Portelli ${ }^{44}$
}

Lynn Abrams reminds us how the oral history interview "is an event of communication, which demands that we find ways of comprehending not just what is said, why it is said and what it means." ${ }^{45}$ Because the interview is a communicative process, it is also, as Abrams points out, a "means to access information but also signification, interpretation and meaning." Therefore, the practice of oral history is intrinsically bound up with theorizing and reinterpreting historical narrative. Moreover, the narrative is in constant flux since the meaning or signification of what is told acquires the category of historical source. ${ }^{46}$ The result is a life story/history which does not seek objective rendition of facts but rather the meaning, the signification, built in the process of exchange product of the so-called inter-subjectivity of the (auto)biographical story. ${ }^{47}$

Lynn Abrams indicates that the theorist adds "performativity" and "mutability" because $\mathrm{s} /$ he is part of a much larger process known as inter-subjectivity and/or collaboration. Therefore, as the historian is drawn into the story, "objectivity" is

44 Alessandro Portelli, "A Dialogical Relationship: An Approach to Oral History," (1985) http://www.swaraj.org/shikshantar/expressions_portelli.pdf.

45 Abrams, Oral History Theory, 1.

46 For Ronald Grele's theory of "conversational narrative," see Grele, "Private Memories and Public Presentation," 257-58.

47 Llona, Entreverse; Domínguez, Benmayor, and Cardinal de la Nuez, Memory, Subjectivities, and Representation. 
impossible. ${ }^{48}$ There is an autobiographical component that I embrace in the narratives that follows what Portelli calls a "composite genre":

Oral sources are generated in a dialogic exchange - an interview-literally a looking at each other, an exchange of gazes [my emphasis]. In this exchange questions and answers do not necessarily go in one direction only. The historian's agenda must meet the agenda of the narrator; what the historian wishes to know may not

Cited in Abrams, Oral History, 19. Some of the oral history seminal works include: Luisa Passerini, Autobiography of a Ceneration: Italy, 1968 (Middletown, CT: Wesleyan, 1996); Fascism in Popular Memory: The Cultural Experience of the Turin Working Class (Studies in Modern Capitalism) (Cambridge, UK: Cambridge University Press, 2009); Alessandro Portelli, The Death of Luigi Trastulli and Other Stories Form and Meaning in Oral History (Albany, NY: State University of New York Press, 1990); Donald Ritchie, Doing Oral History (Oxford Oral History Series), $3^{\text {rd }}$ ed. (Oxford: Oxford University Press, 2014); Paul Thompson, The Voice of the Past: Oral History (Oxford: Oxford University Press, 1988); Alistair Thomson, Anzac Memories: Living with the Legend (Manchester: Manchester University Press, 2011), as well as Thomson and Anisa Puri, Australian Lives: An Intimate History (Victoria, AU: Monash University Publishing, 2017); and more recently Paula Hamilton's work on the role of the senses in oral histories: Paula Hamilton, "The Oral Historian as Memorist," The Oral History Review 32, no. 1 (Winter - Spring, 2005): 1118; and Graham Smith's current work on food and family relations and doctor-patient memory narratives. Some works on Spanish historiography include: Pilar Folguera, Cómo se hace historia oral (Madrid: Eudema, 1994); Miren Llona, Entre señorita y garçonne. Historia oral de las mujeres bilbainas de clase media (1919-1939) (Málaga: Universidad de Málaga, 2002); Mercedes Vilanova, "El combate en España por una historia sin adjetivos con fuentes orales," Historia Antropología y Fuentes Orales, 14 (1995); Cristina Borderías, "La historia oral en España a mediados de los noventa," Historia Antropología y Fuentes Orales, 13 (1995); Miren Llona, "Memoria e identidades: Balance y perspectivas de un nuevo enfoque historiográfico," in La historia de las mujeres: Perspectivas actuales, by Cristina Borderías (Barcelona: Icaria, 2008), as well as Miren Llona, "Archivar la memoria, escribir la historia: Reflexiones en torno a la creación de un Archivo de Historia Oral. AHOA, Ahozco Historiaren Artxiboa," in Historia Oral. Fundamentos metodológicos para reconstruir el pasado desde la diversidad, ed. Laura Benadiva (Rosario: Suramérica Ediciones, 2010); Elena Hernández Sandoica, Tendencias historiográficas actuales (Madrid: Akal, 2004). It is impossible to do justice to the voluminous oral history literature, today a truly global interdisciplinary field across cultures. Some of the best information is available online at the Columbia Center for Oral History (CCOHR) http://www.incite.columbia.edu/cco hr/; the Oral History Association http://www.oralhistory.org/resources/; and the International Oral History Association provides a good bibliography http://www.ioha.org/useful-readings/ . In Spain see the following archives: In Madrid late Professor Carmen García Nieto from the Universidad Complutense de Madrid established in 1981 the Seminario de Fuentes Orales ht tp://www.seminariofuentesorales.es/somos/somos.php to explore the experiences of women during the Spanish Civil War; in the Basque Country professor Miren Llona from the Universidad del Pais Vasco leads the establishment of the Archivo de Historia Oral. AHOA, Ahozco Historiaren Artxiboa http://www.ahoaweb.org/. 
necessarily coincide with what the narrator wishes to tell. As a consequence, the whole agenda of the research may be radically revised. ${ }^{49}$

It is a composite genre, the narrative resulting from the collaborative process between interviewer and interviewee, a process Miren Llona calls "entreverse" (to see each other). Far from being a mere declaration from the informant, it is a two-directional exercise that reveals through the production of that composite narrative the inter-subjectivity involved in the historical becoming. Likewise, autobiographical information provides insights into hidden aspects of mainstream historical narratives and how the actors negotiate their understanding of their "selves" in the context and in response to the master narratives or ideological parameters of the time and place discussed. ${ }^{50}$ The individuals that I interviewed told their stories within the parameters of the gender ideology of Francoism, which articulated what I have called "True Catholic Womanhood." Some elaborated a sense of self in opposition to the conventions of the time, while others tried to take advantage of those same parameters (piety, modesty, motherhood) to assert themselves. The narratives constructed respond to each person's gender, class, political and subjective appraisals of the past events, and experience of the political and social events. The oral historian, therefore, must incorporate into his/her methodology the cultural and communicative memories that frame the narrative.

As we will examine in the narratives that follow, the city of Granada becomes the site of encounter between the repressive forces of the Francoist state apparatus against the students and workers and, simultaneously, the site where individuals reclaimed their sense of individuality and group consciousness. They trespassed physical and symbolic boundaries laid out, with technocratic precision, by urban planners. Within the city they moved from the middle-class urban center to the newly established marginal developments and shanty towns, and from the learned

49 Portelli, "A Dialogical Relationship."

50 Portelli identifies three narrative models: institutional, communal, and personal. The first is told in the first person and refers to political and economic themes; the second utilizes the "we" to tell the collective actions and is located in the workplace and neighborhood; finally, the third is the personal that reveals intimate, family, and domestic events. All three interact and inform each model. This process is known as the "theory of composure," which puts in contact on the one hand, the format of the narration (epic, romantic, heroic) proper of the time period the memories are produced, and on the other hand, the way the informant constructs his/her self in an effort to reconcile personal and collective themes. On the theory on composure see: Abrams, Oral History Theory, 66-67. Penny Summerfield has further problematized the concept of composure by proposing the process of "de-composure" when some of the informants depart from community conventions rather than reconcile their personal and collective identities. See Penny Summerfield, "Discomposing the Subject: Intersubjectivities in Oral History," in Feminism and Autobiography: Texts Theories, Methods, ed. Tess Cosslett, Celia Lury, and Penny Summerfield (London, New York: Routledge, 2000), 91-94. 
male-centered university space to the working-class suburbs. These perambulations generated a rhythm, a pulse of the city we retrieved and relived through the interview process, turning the spatial into a doorway to the temporal as well. As the informants recall and retell their experiences in prison, at neighborhood associations, or as members of the Communist party cells, I, the author, turn into a Flâneur, not of concrete streets but rather of the memory lanes those spaces evoke in our conversations. In a poetic fashion, my "self" is part of the story. Their stories were/are my story. Like Alice in Wonderland, I alternate between becoming big, as adult writer/historian, or small, as I go back in time to involuntary memories triggered by the narratives. The universal and the individual reconcile in this microspace of Granada where I came of age. I can taste, smell, and hear the Granada of my childhood in their recounting. In our conversations is a communion-a historical transubstantiation. Authenticity trumps old-fashioned clinical "objectivity," turning the quest for truth into emotional authenticity.

The two groups of women (college and working class) I interviewed, over a span of more than twenty years, told me stories that might be retold in a different fashion now. I was not the same interlocutor in 1989 as in 2004, and my interaction and collaboration in the creation of these primary sources has evolved as well. Therefore, the resulting study is not only a collection of oral histories to voice the voiceless, but rather an attempt at signification. Passerini made clear in her study of fascism in 1979 that oral sources, rather than telling us about historical facts, provide insights into the subjectivity of the informant and the context in which the communicative process of the interview takes place. Passerini made us appreciate and pay attention to silence and the seemingly irrelevant responses of her interviewees when she asked them about fascism. My Spanish interviews came to fruition (or not), depending on what the informants might have sensed about where my sympathies to Francoism lay. In some instances, they declined my request to interview them because the book had a feminist approach. Unavoidably, I am part of the narrations that follow.

Both Henri Lefebvre and María Zambrano insert their living selves into their intellectual pursuits. In both cases, we encounter a reference to the new beginning, a point of inflexion and change that utilizes the symbol of the crucified sun in the case of Lefebvre and the poetic notion of the dawning thought (pensamiento auroral) in Zambrano. Both thinkers resort to light, the sun, and sunrise as an opportunity to criticize modernity, capitalism, and the discarding of humanness from Western thought.

In his autobiographical book La somme et le reste (1959), Lefebvre recounts a vision of the "crucified sun" he had in his youth in the 1920 s when he was visiting the Pyrenean countryside. While on a walk, he saw a cross with a circle surrounding it. "They had crucified the sun!" Lefebvre asserts: 
I no longer saw the cross of Christ wreathed in solar glory or surrounded by the crown of thorns, as had been explained to me, but the darkened sun, marked by a black sign, nailed to the Christian cross. The sun was youth, brilliant [l'êclarite] my own, but overcast, pinned down by mental, sexual, and social misery. It was the heat of vitality the ardor of energies fallen into the coldness of the void and its sign. Even in the research bearing the name which had appeared so beautiful to me for a long time: Philosophy. ${ }^{51}$

La somme et le reste was written in 1959, two years after Lefebvre had been expelled from the French Communist Party. He had joined the party not to enter politics but because he felt it was the answer to the end of politics. The symbol of the crucified sun reappears in other writings, and it becomes Lefebvre's metaphor of choice to criticize modernity and the alienation of the urban masses. While the sun represents all that is vital and full of life, the cross embodies repression and alienation in life. The metaphor also made him sensitive to the significance of what that moment of realization had in his life and his thinking. Moreover, it made him aware that certain moments themselves were important turning points in the human experience. ${ }^{52} \mathrm{~A}$ singular moment is full of potential, transcendent, when the individual is radically free to make a decision that will affect his/her destiny.

Since oral history and memory intertwine in Maria Zambrano's exploration of the dictum "I am I and my circumstance" that her teacher Ortega y Gasset articulated through his ratio-vitalism, we can explore the historiographical mandate of truth and objectivity. Zambrano carries further the radical view "I am I and my circumstance" by contemplating the emotional nerve in human thinking processes. She puts it this way: "In the deepest realm of the howling, the weeping, and the groaning resides the core, the insoluble seed of our being, of the word itself." 53 That emotional element only emerges through poetry, revealing an authentic universal being rather than simply a factual objective representation. Zambrano reinterpreted "I am I and my circumstance" and the radical reality of historicity by appealing to the emotions of the human condition. The human subject, the "I," is conscious of his/her self in the measure s/he embraces his/her temporality and its context; it is up to the individual to shape his/her destiny in the face of conventional conditions of a particular time and place. In other words, "I" only becomes "I" in interaction with an "Other." The practice of oral history turns into the most useful tool to achieve historical authenticity—variations of being in the world in time.

\footnotetext{
51 Henri Lefebvre, La somme et le reste, quoted in Elden, Understanding Henri Lefebvre, 170-71.

52 Elden, Understanding Henri Lefebvre, 171.

53 En el interior más hondo del reino del sollozo y del llanto y del gemido habita tal vez el núcleo, semilla indisoluble ha de ser, de la palabra misma [...]." [my translation], in María Zambrano, De la Aurora (Madrid: Tabula Rasa, 2004), 124.
} 
Out of this communicative experience arises the "Thinker/Historian as Poet." The historian turned thinker does as the poet: poetiza, compone, articula (poeticizes, composes, articulates). ${ }^{54}$ Poetic reasoning maintains rigor and critical insight while making the symbolic nature of language work in its favor, opening the door to the emotions and malleable nature of the human condition. Zambrano suggests that the purpose of thinking is "to open up and take true measure of the dimension of our existence." 55 Such introspection is what will make possible the unveiling of the authentic gendered being I am pursuing in the analysis of these interviews. Such thinking is a recalling, remembering, memorization, but also a responding and an autobiographical immersion into the analysis. Past and present meet in the moment informant and historian talk to each other.

54 Martin Heidegger, Poetry, Language, and Thought (New York: Harper Perennial Modern Classics, 2013), xi.

55 Ana Bundgaard, "Ser, palabra y arte: El pensar originario de Martin Heidegger y María Zambrano," in Aurora: Papeles del "Seminario María Zambrano," 12 (2011): 7-12. 
